\title{
LAJOS VÉKÁS•
}

\section{The Foreseeability Doctrine in Contractual Damage Cases}

\begin{abstract}
This study makes the proposal to introduce the contract remoteness test into the Hungarian civil law as a principal restriction on compensatory damages. The author sums up the development of the reasonable contemplation test in the English common law first formulated in Hadley v. Baxendale. He compares it with Art. 1150 of the Code civil, Art. 252 of the German BGB and Art. 74 of the Vienna Sales Convention, before making his proposal for the new Hungarian Civil Code.
\end{abstract}

Keywords: Hungarian civil law, contracts, contractual damages

One of the most remarkable aspects of the uniquely productive publishing work of Gyula Eörsi is the legal scientific work he did analyzing various aspects of liability for damages. ${ }^{1}$ It is exactly for this reason that we chose a problem of tort liability as the focus of this publication dedicated to his memory. The choice of topic was also influenced by the fact that Eörsi's work in legal theory was most notably well received internationally when contributing to the framing of international sales law. Professor Eörsi belonged to the select group of experts who participated already in the development of The Hague Sales Convention ${ }^{2}$ that was adopted as early as

- Lajos Vékás, Member of the Hungarian Academy of Sciences, Budapest, H1053 Budapest, Egyetem tér 1-3., Hungary.

E-mail:vekas@ludens.elte.hu

${ }^{1}$ Compensation for Illegal Behavior. Budapest, 1958. Attempt at Drafting a Uniform System of Respons Under Civil Law. Hungarian Academy of Sciences Társadalom-történeti Osztályának Közleményei IX (1959) issue No. 2. Fundamental Problems of Legal Responsibility, Responsibility under Civil Law. Budapest, 1961; Problems of demarcation in the sphere of financial responsibility. Budapest, 1962; Handbook of Compensatory Liability in Civil Law. Budapest, 1966.

${ }^{2}$ Schlechtriem, P. (Hrsg.): Kommentar zum einheitlichen UN-Kaufrecht (CISG). München, $2000^{3}, 28$. Gives a rather witty parody of the proceedings and atmosphere 
1966, and he was also an important participant in the work done within the framework of UNCITRAL. In addition to the general international respect he commanded it was probably for this latter reason that he was elected President of the Diplomatic Conference ${ }^{3}$ held in spring of 1980, which adopted the Vienna Sales Convention that currently has more than 50 member states. ${ }^{4}$

\section{Limiting Liability for damages in Hungarian Legal Theory and Practice $^{5}$}

1. The starting point for the regulation in the Ptk. (Civil Code, hitherto C.C.) $[339 \S$ paragraph (1)] regarding the amount of damages to be paid is the principle of full compensation, and accordingly no statutory exemption is provided within the general rules in the area of contractual damages. The possibility of partial judicial relief from liability for loss on the basis of equity [339. § paragraph (2)] is only available in the case of tort damages [318.§ paragraph (1)]. ${ }^{6}$ On the basis of judicial practice of more than forty years it can also be seen that judges did not exercise their freedom to grant partial relief allowed by law on the grounds of fairness in noncontractual damage cases either. ${ }^{7}$ Instead, if they deemed it appropriate

of the law-unification conferences Eörsi: Unifying the Law (A Play in one Act, With A Song). Am. J. Comp. L. 25, 1977. 658-662.

3 Eörsi co-authored one of the first commentaries of CISG giving explanations of Articles 14-17 and 55: Bianca, M. C.-Bonell, J.: Commentary on the International Sales Law (The 1980 Vienna Sales Convention). Milan, 1987.

${ }^{4}$ For the list of member states see Magnus, U.: Wiener UN-Kaufrecht (CISG), in: Staudingers Kommentar zum BGB, Berlin $1999^{2}$, page 27 at seq.; Mádl, F.-Vékás, L.: Nemzetközi magánjog és nemzetközi gazdasági kapcsolatok joga (International Private Law and Law of International Economic Relations). Budapest, 20005. 322. et. seq.

5 For a comparative law outlining of the problem see Hellner, J.: The Limits of Contractual Damages in the Scandinavian Law of Sales. Scand. Stud. Law, 10 (1966) 37-79. (40. et. seq.).

${ }^{6}$ We mention that Swiss Contract-Law (OR) charges the judge with deciding the nature and size of the damage to be awarded, especially in tort cases (Art. 43, Art.99).

7 Even the original intention of law makers suggested applying C.C. § 339. 2nd paragraph allowing mitigation of liability based on fairness only in "extraordinary cases". Cabinet Minister's Explanation for the quoted segment of the law". Indeed, legal practice used the fairness principle sparingly, which was also the recommended 
given the circumstances of a particular case, judges would partially relieve the party causing the loss from liability based either on insufficient demonstration of proof, or by limiting the chain of causality. It is difficult to answer the question whether a similar reduction of damages can actually be observed in contractual liability cases. We may assume this to be a good probability, however, this could not actually be proven completely, let alone quantified, as we are limited by the abridged nature of the case reports.

It can be seen that although practice has (correctly) allowed for exceptions (from the principle of full compensation, nonetheless, court decisions on limiting liability for damages chose not to utilise the possibility of equityoffered by the C.C. even in tort cases. Most often they argue for a partial dismissal of claims for damages by pointing to a loose or distant causal relationship between injurious action and loss. At the same time, analysis of the judicial practice also shows that court practice did not draw such a clear distinction between contractual and tort liability in this regard as theintended. ${ }^{8}$

Reducing liability by way of drawing the boundaries of causality, primarily with the application of the so called principle of adequate causality, or by other means of limiting causality based on the cause being "too distant", "non-decisive" or "irrelevant" may in no way be disapproved. Most notably in German law, but also in Common Law, courts employ this method, and international scholarly literature also treats the problem as being an issue partially of causality and partially of distribution of risk. We should note, however, that in the world of contracts, (especially commercial contracts), the viewpoint of distribution of risk is dominant. Furthermore, the problem of causality is widely known to be a difficult

position of the Supreme Court in its opinion coded PK 804/1. In the BH there were only two cases published in 1961 where the possibility of using $\S 339$. 2nd paragraph presented itself. In one of these cases the Supreme Court brought a questionable decision to apply the fairness principle (BH 1961/issue 12, No. 3024), in the other case it correctly decided against such application (BH 1961/issue 6, No. 2910). The rule's application was triggered expressly by the injurious party's financial position in case coded LB Pf. III. 21027/1970 (this case is commented on by Petrik: Law of Compensation. Budapest, 1991. 33).

${ }^{8}$ The justification given by the Minister in an explanation attached to C.C. $\S$ 318. for the exclusion of the liability mitigating fairness principle from contractual cases is as follows: This differentiation "is mostly explained by the position that it would not be justified to provide relief of liabilities fixed in a contract, i.e. such liabilities that could be foreseen." In borderline cases, such as violation of a protected interest by breach of contract, however even the Minister's explanation thought it possible to allow the judge the use of fairness to mitigate liability. 
one bearing a lot of uncertainty. As a result, decisions arguing a lack of causality are often disputable and not always detailed enough, and legal literature is also correct in challenging the erroneous theoretical foundation of the principal of adequate causality. It is correctly argued by Géza Marton that this particular way of mitigating compensatory damages transforms the fundamentally legal policy problem of liability into the more matter of fact question of causality. Consequently, Géza Marton ab ovo proposes the principle of "adequate set-off" instead of adequate causality. According to his correct views the practice of limiting liability for damages by way of limiting causality in cases of liability based on fault would be understandable, although, even here its foundation in theory is flawed. However, in the area of liability independent of fault the logic of adequate causality is even methodologically inappropriate, because this way of cutting the chain of causation at a standardized point applies the notion of typified fault even in a system of relief from liability independent of fault. ${ }^{9}$

2. In the case of Hungary the Vienna Sales Convention has been in effect since January 1, 1988. ${ }^{10}$ Consequently, in matters of international sales Hungarian Law applies the rule (Article 74, 2nd sentence) of that Convention, which in the case of contractual damages limits compensatory damages to only those foreseeable by the injured party, thereby deviating from the principle of full compensation. Compensation amounts awarded as reparation for breach may not "surpass the loss that at the time of concluding the contract could or had to have been foreseen by the breaching party based on those facts and circumstances that had to be considered as the possible results of a breach".

In reference we mention here that in the case of a special problem involving the liability of a freight forwarder the C.C. itself operates on the principal of foreseeable damages. $500 \S$. paragraph (1) states that beyond the agreed penalty for late performance a freight forwarder is only responsible for a loss occurring as a result of late delivery if he agreed to the delivery date in knowledge of the other party's interest intimely performance. ${ }^{11}$

\footnotetext{
${ }^{9}$ Marton, G.: A polgári jogi felelősség (Responsibilities Under Civil Law). Budapest. 1992, item No. 121, 222.

${ }^{10}$ Law-decree No. 20. of 1987; compare with Sándor, T.: A nemzetközi adásvétel (International Sales). Budapest, 1990.; Mádl-Vékás: International Private Law and Law of International Economic Relations. op. cit. chapter 22 (322-349).

${ }^{11}$ It is worth mentioning, probably not as a coincidence, that in English common law the first court case to be built on the principle of foreseeability (Hadley v. Baxendale to be discussed below) has at its center the awarding of unrealized profit
} 
3. As a preliminary remark we also point out that the availability of possible mitigation of tort liability and its dogmatic method seem to show a close connection with the method of relief from liability, and in fact can only be analyzed together. This is clearly shown in the practical application of the principal of adequate causality, and its previously mentioned well founded criticism in legal literature. The C.C. could only provide a special "emergency exit"-like method of mitigation of liability based on the court's discretionary application of the equity principle because it opened a rather wide and moreover flexible window for exculpation with the possibility that the party causing damages prove that he acted "as it can normally be expected under the given circumstances".

The Vienna Convention allows only for a more stringent and objective way of exculpation. According to the Convention a party can only be relieved of responsibility for partial non-compliance if it proves that said default resulted from an obstacle that it could not have circumvented, nor could it reasonably be expected that at the time of conclusion of contract the obstacle be foreseen, removed, or its consequences be averted. ${ }^{12}$

4. The theoretical need for full compensation of damages resulting from breach of contract had been a persistent problem in C.C.'s judicial practice, which is also reflected in legal literature. As early as 1971 Miklós Világhy saw the need for the correction of the principle of full compensation in the contractual domain and similar ideas have been raised by Attila Harmathy a few years later. In 1993 Tamás Tercsák wrote a comparative study dealing explicitly with the question of limiting liability for damages with the help of foreseeability. ${ }^{13}$

occurring as a result of late performance of a transportation contract. Furthermore, leading even today's leading British handbooks discuss the topic with a focus on besides contracts of sale those of transportation. See for example McGregor, H.: On Damages. London, $1997^{16}, 182$ et. seq.

${ }^{12}$ A translation of Article 79 paragraph (1) given by the author that is true to the original English text and therefore differs slightly from the official text published with Law-decree 20 of 1987.

${ }^{13}$ Világhy, M.: A Polgári Törvénykönyv felülvizsgálatának elvi kérdései II. (Theoretical Questions of the Revision of Hungarian Civil Code. (C.C.) II.), Hungarian Law, XVIII. 1971. 456; Harmathy, A.: Felelősség a közremüködőért (Responsibility for intermediary third party). Budapest, 1974. 243-251; Tercsák, T.: Előreláthatóság mint a szerződésen belül okozott kár megtérítésének korlátja (Foreseeability as the Boundary of Compensation for Damages Caused within the Framework of a Contract). In: Polgári jogi dolgozatok (On Civil Law), (ed.: Harmathy, A.). Budapest, 1993. 231-254. 
Világhy proposed the tightening of the rules governing the finding of liability in cases of defective performance and simultaneously proposed the need for an exception to the rule of full compensation. (We should mention that before the 1977 Novella has entered into force the C.C. awarded a claimant compensation after the expiration of the warranty period only in very limited cases [original 307. § paragraph (2)]: in order to be awarded compensation the entitled had to prove that the defaulting obligor acted fraudulently.) In limiting liability for damages he did not rule out the introduction of the foreseeability principle based on "the inspiration of English or French law and legal practice" as such a solution that "theoretically meets the criteria of the concept of contractual barter relationships". However, instead of introducing this principle "foreign to Hungarian legal thinking" by way of legislation, he rather suggested that "in legal regulation of the actual sum of damages a judicial practice would develop in the direction of the so called adequate causality principle and as a necessary consequence courts would award only that portion of contractual damage that the parties had to have considered at the time of breach given the particular nature of the terms of the contract." Although here is little difference with regard to their effect, the foreseeability principle and the principle of adequate causality differ significantly in terms of their theoretical foundation, as this was pointed out above when discussing ideas of Géza Marton. While the predictability principle allows the normative limiting of making a party liable for damages based on a decision of policy, the doctrine of adequate causality provides a tool for artificially breaking of the existing causality chain based on a judge's discretion. Világhy would solve the problem of how to flexibly limit the principle of full compensation in a way that would also provide a platform for a more organic development of law. He favored the use of the less unusual principle of adequate causality, deciding not to bother with the rather well founded theoretical criticism that were certainly known to him as well. Law No. 4 of 1978 essentially chose this same direction recommended by him. According to this law that is still in effect to this date the C.C. theoretically extended the defaulting obligor's liability over all damages even beyond the warranty period, and left their potential mitigation up to the judge. Even today the methodology of mitigation can be based (of course not overtly) on the principle of adequate causality. This is certainly a faulty solution in terms of its foundation in theory.

In his excellent monography on the subject of responsibility for the acts of intermediaries, Harmathy also deals with the issue of defining the limits of claims of contractual damages. In building a foundation for his 
deductions he gives a short yet sophisticated comparative law study on the dogmatic tools used to limit the size of damage awards in French, English, and German law as well as in Hungarian draft codes and socialist law. He sums up his position by writing that "there is a need across the board for limiting liability over breach of contract. This is understandable because at the time of the conclusion of the contract the parties take into account a certain risk, a possibility of loss during the normal run of the process, and they agree on stipulations of the contract with these eventualities being taken into consideration." In his summary he explicitly argues for the condition of "foreseeability" to be inserted into the process of limiting liability for damages caused by contract violation, because this solution is "most sensitive to business considerations". For establishing the forseeable amount of damages Harmathy suggests we simultaneously take into account both objective and subjective criteria. "An objective characteristic exists in that those parts of damage are included which given the particular circumstances had to be taken into account based on prior knowledge or experience; a subjective one, in that we take into account also that part of the damage which although could not be expected based on experience, but the person in breach of the contract came to possess such facts at the time of contract talks and the fixing of the terms of the contract, that would have suggested the probability of the occurence of higher than usual damages."

Tercsák finds it desirable to limit liability for damages to foreseeable damages in the area of contractual liability law based both on the grounds of economic rationality and as a measure of prevention. He compares this solution with various other methods of limiting liability for damages used in some of the more important legal systems, for example schemes that define liability for compensation as a direct function of the degree of culpability, or the use of assorted causality theories, etc. As his ultimate conclusion he proclaims that in the area of compensation for contractual damages boundaries of liability can be drawn most accurately with the aid of the foreseeability method compared with all others.

5. In the following section we analyze the foreseeability doctrine. Our purpose is to contribute to the effort to reform the C.C. by providing an alternative solution to the problem of limiting liability in damages arising from breach of contract. ${ }^{14}$ Providing such an alternative solution may be

\footnotetext{
${ }^{14}$ Sándor also recommends the solution of the Vienna Convention for the reform of the C.C.: Sándor: International Sales. op. cit. 276. footnote 9.
} 
necessitated particularly by the fact that the reform of the C.C. is expected to bring about changes in matters of exculpation. ${ }^{15}$ This is important, because if proof of lack of culpability is not sufficient grounds for relief (as it is suggested in the new Concept of C.C.), rather it is necessary to provide proof of objective circumstances (similarly to the provisions of the Vienna Convention), then a more robust, and more importantly, a more predictable foundation must be provided for the limitation of liability as well, in comparison with the current state of affairs. The foreseeability doctrine would provide an internationally common and successful dogmatic framework for this issue.

\section{The Foreseeability Doctrine and its Related Institution in National Laws}

1. The foreseeability doctrine was likely approved relatively easily as part of the Vienna Convention because it is known in the several highly regarded legal systems. ${ }^{16}$

a) In modern times it makes its first appearance in French Law, ${ }^{17}$ from which it spread to most legal systems, fashioned after French codification. The Code civil itself expressly states (Article 1150.) the requirement of foreseeability in determining the amount of damages.

In French legal practice, however, this method of reducing compensation awards does not play a major role. This is in part due to substantive law reasons. As a matter of course the Code civil precludes the case of intentional breach of contract ("par son dol") from the scope of operation of the foreseeability principle. A further restriction in the application of the principle results from a unique distinction in French civil law between "obligation de résultat" and "obligation de moyens". Moreover, it is superfluous to refer to the necessity of foreseeability due to the special legal

${ }^{15}$ Compare with Vékás, L.: Javaslat a szerződések általános szabályainak és a szerződéstípusok szabályainak korszerüsítésére (Vitaindító tézisek az új Ptk. Koncepciójához, II. Rész). Polgári jogi kodifikáció III. évf. [Recommendation for the updating of the general rules of contracts and rules governing various contract types. (Debate opening theses for the new concept of the C.C., part 2). Codification of Civil Law], vol. 3. 2001. issue 4-5.

${ }^{16}$ Hellner: The Limits of Contractual Damages... op. cit. 47., with footnote's 3 and 4.

${ }^{17}$ Dupin, A. M. J. J. (ed.): Oeuvres de Pothier, contenant les traités du droit français. Paris, 1824. 1. k.: Traité des obligations, Nr. 159. et. seq. For the roots of the principle in Roman law see Zimmermann, R.: The Law of Obligations (Roman Foundations of the Civil Traditions). Cape Town, 1990. 829. et. seq. 
exemptions given both in the general rules of contracts (Article 1153.) and in contracts of sale (1630. and following Articles, Article 1644.). ${ }^{18}$ In addition to these reasons we should also consider the procedural matter that a claim based on the foreseeability doctrine (being a legal objection presuming deliberations of fact) may not be raised before the Cour de cassation.19 Finally, the less frequent use of the foreseeability rule can most likely be attributed to the fact that beyond the scope of damnum emergens and lucrum cessans the Code civil (Article 1151.) limits compensatory damages to the immediate and direct ("immédiate et directe") consequences of the breach of contract .

b) A significantly more important role is played by the foreseeability doctrine in English common law.

In English judicature this principle was first applied in Hadley v. Baxendale $^{20}$ by the Court of Exchequer. At the heart of this often quoted case was the dispute between a mill owner and a carrier. A part of the steam mill that had been off site for a necessary repair was delivered back to the mill only four days past the time of delivery that the carrier had agreed to and the miller sued the carrier for lost revenues. It is an interesting example of the unpredictable interactions that the history of law can produce that in this case the plaintiff's attorneys and one of the judges referred to French Law $^{21}$ based on an American textbook. ${ }^{22}$ The

${ }^{18}$ Mazeaud, H.-Mazeaud, L.-Mazeaud, J.-Chabas, F.: Traité théorique et pratique de la responsabilité civil délictuelle et contractuelle. 3/1. Vol. Paris, $1978^{6}$, Nr. 2190 (compare with Nr. 2378 and 2390 as well); Ghestin, J.—Desché. B.: Traité des contrats - La vente. Paris, 1990, Nr. 853. et. seq.

${ }^{19}$ Viney: La responsabilité: effets. Paris, 1988, Nr. 324.

${ }^{20}$ (1854) 9 Exch 341156 Engl. Rep. 145(1854); for more recent analyses of the case see.: Danzig: Hadley v. Baxendale: A Study in the Industrialization of the Law. Journal Legal Studies. 4 (1975) 249-284.; Faust: Hadley v. Baxendale — an Understandable Miscarriage of Justice. J. Legal Hist. 15 (1994) 41-72.; also compare with Zimmermann: The Law of Obligations... op. cit. 830.

${ }^{21}$ Hadley v. Baxendale, (1854) 9 Exch 341, 345 et. seq. According to the transcript Judge Parke said the following during the trial: "I wish the sensible rule was established, that damages must be confined to what the parties reasonably anticipated. My attention has been drawn to the subject by reading Mr. Sedgwick' work." Hadley v. Baxendale, 23 L.J.R. [N.S.] Exch 179, 181 (1854). (Eörsi was known to enjoy "playing around" with English cases.) Pothier's views were incidentally fondly adopted by English decisions of the 19th century, in fact according to König (Zimmermann: The Law of Obligations... op. cit. 336., 830.) the concept of foreseeability can be traced back to Dumoulin in French private law (Molinaeus. C.: Tractatus de eo quod interest: 1546): König: Voraussehbarkeit des Schadens als Grenze vertraglicher Haftung — zu 
decision that was handed down in the case was written by Lord Alderson of the four judges produced an important procedural innovation not relevant to our subject, but it also contained a legal argument that was likely flawed considering the particulars of the case which led to an unjust resolution. ${ }^{23}$ Nonetheless, to this day it is regarded as the leading precedent in English Law ("the most celebrated case in the field of contract damages" 24 spelling out the the clause of forseeability, the "contemplation rule" (or "contemplation doctrine"). The holding of this famous judgment is that in a case of breach of contract, in addition to "general damages" (i.e. actual losses), such additional damages may be claimed on the basis of unrealized profit "as may reasonably be supposed to have been in the contemplation of both parties, at the time they made the contract, as a probable result of the breach of it". ${ }^{25}$ Dicta to the judgment emphasizes that if the party in breach could be made liable for that part of the damage which he did not have to foresee at the time of breach, then it would not be in the injured party's interest to come to an agreement with the other party regarding the probable damages resulting from a possible breach. By the same token, the party later to be in breachcould not effectively protect himself from larger consequential damages by the appropriate limiting of his liability with suitable contract terms. ${ }^{26}$ The foreseeability doctrine became a general principle of English judicial practice after 1854 and this remained unchanged after the 1893 Sale of Goods Act and even after its 1979 reform (Section 54). ${ }^{27}$

Art 82, 86, 87 EKG, in: Das Haager einheitliche Kaufgesetz und das deutsche Schuldrecht. (Hrsg.: Leser/von Marschall), Karlsruhe, 1973. 75-130. (76. et. seq.).

${ }_{22}$ Sedgwick, Th.: A Treatise on the Measure of Damages. New York, 1847, 64. et. seq.

${ }^{23}$ Danzig: Hadley v. Baxendale: A Study in the Industrialization of the Law. op. cit. 260.; Faust: Die Vorhersehbarkeit des Schadens gemäß Art. 74. Satz 2 UNKaufrecht. Tübingen, 1996. 80. et. seq.

${ }^{24}$ McGregor: On Damages. op. cit. 157.

${ }^{25}$ Bradley, J.: (1854) 9 Exch 341, 354; in English literature foreseeability is also known as ,test of remoteness”.

${ }^{26}$ Ibid. 355 , the following English court cases contributed significantly to solidifying or advancing the foreseeability doctrine: Victoria Laundry (Windsor) Ltd. v. Newman Industries Ltd. (1949) 2. K.B. 528.; Monarch Steamship Co. Ltd. v. Karlshamus Olejfabriker (A/B) (1949) 196., 224. The best guide to the development and subproblems of the principal in English law are given by Ogus, A.: The Law of Damages. London, 1973. 71-79; McGregor: On Damages. op. cit. 157-184. (items 247-281).

${ }^{27}$ Ogus: ibid.; McGregor: ibid.; Guest, A. G.: Benjamin's: Sale of Goods. London, $1997^{5}, \S \S 16-040$ (856), 17-001 (894), 17-045 (929); also compare with Faust: Die Vorhersehbarkeit des Schadens... op. cit. 82. et. seq. 
c) United States judicial practice also applies the contemplation rule as a classic common law principle. ${ }^{28}$ UCC $\$ 2-715$ (2) (a) spells out in detail the rule of contemplation with regard to consequential damages in the buyer's assets: "Consequential damages resulting from the seller's breach include any loss resulting from general or particular requirements and needs of which the seller at the time of contracting had reasonably to know and which could not reasonably be prevented by cover or otherwise". ${ }^{29}$ It is important to point out that UCC [§ 2-715 (2) (b)] does not apply the contemplation rule for damage to the buyer's person or property "resulting from any breach of warranty".

2. Although the BGB chose a slightly different path when limiting liability for damages the English "contemplation rule" managed to find its way into German jurisprudence as well. ${ }^{30}$ Incidentally, the solution found in BGB is also interesting as well as instructive. ${ }^{31}$ Besides limiting claims of unrealized profit to the amount that could be expected with good probability (252. §), the German code allows for the reduction of damages within the context of the claimant's responsibility to prevent damages

\footnotetext{
${ }^{28}$ Howard v. Stillwell and Bierce Manufacturing Co., 139 U.S. 199, 208 (1891); Primrose v. Western Union Telegraph Co., 154 U.S. 1, 29(1894) etc. According to König American judicial practice had applied the foreseeability principle even prior to Hadley v. Baxendale: Sedgwick: A Treatise on the Measure of Damages. op. cit. 80. et. seq.

${ }^{29}$ The UCC gives no particular rule for damages suffered by the seller due to the buyer's violation of contract terms. This one-sided feature is duly criticized in the literature White, J.-Summers, R. S.: Uniform Commercial Code, vol. 1, St. PaulMinn, $1995^{4}$, 412. et. seq. However, the literature also correctly points out that the buyer's potential late payment is a possible cause of loss liability that can generally be estimated with good accuracy ahead of time. Hellner: The Limits of Contractual Damages in the Scandinavian Law of Sales. op. cit. 78. et. seq. Huber, P.: Leistungstöhrungsrecht. vol. 2. Tübingen, 1999, 264. 3. footnote.; compare with Schwenzer, I.: Freizeichnung des Verkäufers von der Sachmängelhaftung im amerikanischen und deutschen Recht. Frankfurt/M. 1979. 38. et seq.

${ }^{30}$ Rabel, E.: Das Recht des Warenkaufs. Vol. 1. Berlin, 1936. (reprint: 1964), 491. et seq.; von Caemmerer, E.: Das Problem des Kausalzusammenhangs im Privatrecht. In: Gesammelte Schriften (vol. I.). Tübingen, 1968. 395. et. seq.

${ }^{31}$ The BGB's damage liability laws were founded on Mommsen's study: Zur Lehre von dem Interesse. Braunschweig, 1855. Mommsen believed firmly in the principal of full compensation: op. cit. 168. et. seq. and the BGB's drafts also kept this principle almost uniformly, compare with Faust: Die Vorhersehbarkeit des Schadens. op. cit. 340. et. seq.
} 
from occurring. According to 254. § paragraph (2) the obligor in breach is not required to compensate for damage that the injured entitled failed to prevent or mitigateby actions of gross negligence. It is considered to be the injured's negligence if, preferably at the time of contracting, he failed to bring to the other party's (the future breaching party's) attention such extraordinary risk of unusually large loss that was neither known nor could have been expected to be known to his partner. ${ }^{32}$

The solution offered by the BGB reaches similar goals to that of the contemplation rule by following a different dogmatic path. In this case risk is considered extraordinary if the level of damage significantly surpasses that which could be expected in a similar business scenario. For example if the result of a late bank transfer is the loss of a patent claim then the resulting damage can be considered unusually high. Naturally, the entitled can only be made responsible for negligence if he himself could have been aware of the nature and size of the damage. The entitled is not under obligation of disclosure if his contractual partner himself knew or had to know the extraordinary risk. ${ }^{33}$ The disclosure of the possibility of extraordinary risk by the obligee can result in the obligor deciding to (in the first three cases, possibly simultaneously):

- pay extra attention to specific performance of the contract

- attempt to limit his risk by stipulations limiting or excluding liability

- raise the price due to increased risk

- decline to enter into contract due to impending large risk.

Grossly negligent failure to disclose facts leads to a division of the loss between the breaching and injured parties. When distributing the burden of loss both the cause leading to the loss and the parties' negligence must be weighed. ${ }^{34}$

The possibility of liability reduction offered by the first sentence of the BGB [254. § paragraph (2)] (which incidentally is also open in tort cases) is very rarely applied in practice. ${ }^{35}$ In tort cases even the rule of the BGB can prevent only the further growth of existing damages such as the one that would result from late payment of a compensation award. ${ }^{36}$ The

${ }^{32}$ Lange, H.: Schadenersatzrecht. Tübingen, $1990^{2}$, 574.; Huber: Leistungstöhrungsrecht... op. cit. 263. et. seq.

${ }^{33}$ Lange: ibid.

${ }^{34}$ BGB Handkommentar. Baden-Baden, 2001. Schulze, R.: ad $\S 254$, Rn. 10.

${ }^{35}$ König: Voraussehbarkeit des Schadens als Grenze vertraglicher Haftung... op. cit. 96.; Tercsák: Foreseeability as the boundary of compensation for damages caused within the framework of a contract. op. cit. 237.

${ }^{36}$ See for example BGH 23.2. 1960, VersR 1960, 526. 
infrequent use of this rule in practice is undoubtedly related to the attitude of the BGB in granting relief from liability (besides being also related to other issues like the limited nature of the concept of lost profit and other restrictions governed by separate laws such as the HGB):as a matter of course, non-negligent breach leads to no liability for damages.

3. In comparing the foreseeability doctrine and the solution provided by the BGB the following may be stated. ${ }^{37}$ Primarily, it is immediately clear that both solutions summarized above effectively surpass either the method of judicial cutting of the chain of causation or discretionary reduction of liability based on fairness in the sense that instead of leaving the key to resolution in the hands of the judge they both hand it over to the parties, and that is a significant plus in contract law.

Almost undoubtedly, the foreseeability doctrine appears to give a more solid and specific point of reference to the contracting party in its effort to size up the risk of entering a contract in advance and make decisions accordingly. At the same time both solutions reflect a market-oriented attitude and treats the parties as sovereign and equal participants of a pecuniary transaction. One side is motivated to disclose risk, the other to evaluate it and base its business decision on that.

The foreseeability doctrine is perhaps a bit more effective in that the obligor can always take into account the increased risk when determining counterperformance. In the case of the BGB this is not always possible because the contracting party is obliged to give notice of a higher risk not necessarily at the time of entering into contract but only when he becomes aware of the risk. Also, the claimant's right to full compensation stays valid if no negligence is involved in his failure to give notice or if his negligence had no effect on the prevention of loss. Conversely, the BGB may be more effective in the actual prevention of loss. While the foreseeability doctrine does not provide cover for risk of loss that increases after the conclusion of contract the BGB makes even that possible as the obligee is required to give notice of higher risk throughout the entire length of the contractual relationship. Moreover the BGB is also a bit more fair in contrast with the foreseeability doctrine in that in the case of increased

\footnotetext{
${ }^{37}$ Compare with Huber: Leistungstörungsrecht. op. cit. 267. et. seq.; Faust: Die Vorhersehbarkeit des Schadens. op. cit. 339. et. seq.; On Limits of the application of the foreseeability principle, see Hellner: The Limits of Contractual Damages in the Scandinavian Law of Sales. op.cit. Especially 77. et. seq.
} 
risk not foreseen by either party responsibility for the risk rests with the party in breach. ${ }^{38}$

However, as far as the effectiveness of either the foreseeability doctrine or the BGB rule is concerned, a hindrance is presented by the fact that (especially in the world of business) contracting parties are reluctant to shed light on their business strategies (often speculations).

Finally, as we pointed out before, in a legal climate where a breaching party has to compensate for losses only in case of negligence, the importance of more subtle dogmatic ways of mitigation of liability is significantly reduced in comparison to a more stringent doctrine of liability. It is also clear that the most accurate (although by far the least harmonious with liberal market philosophy) tool of defining risk is the capping of liability by law. This solution is rather common in the area of freight forwarding and transportation contracts. ${ }^{39}$

\section{The Foreseeability Doctrine in International Conventional Sales Law and in Model Laws}

1. The foreseeability doctrine-based on $R a b e l^{40}$ - was an almost unchallengeable part of even the earliest drafts $(1935,1939,1963)^{41}$ intended to uniformly regulate international sales law, so it was almost natural that it became part of the Hague Sales Convention ${ }^{42}$ (Articles 82 and 86$)^{43}$ and from here a direct path led to Article 74 of the Vienna Sales Convention. ${ }^{44}$ There are only subtle differences in wording between the latter and the above mentioned rule of the Hague Sales Convention and according to the

${ }^{38}$ Same as Faust: Die Vorhersehbarkeit des Schadens... op. cit. 344.

${ }^{39}$ Compare with Huber: Leistungstörungsrecht. op. cit. 267. et. seq.

${ }^{40}$ Rabel: Das Recht des Warenkaufs. op. cit. 495-511.

${ }^{41}$ See Hellner: The Limits of Contractual Damages in the Scandinavian Law of Sales. op. cit. 47., footnote No. 3.

42 July 1st, 1964; compare with Mádl-Vékás: International Private Law and Law of International Economic Relations. 320. et. seq.

${ }^{43}$ Compare with Dölle, H.-Weitnauer, W.: Einheitskaufrecht. München 1976, 531. et. seq., 537. et. seq., directly to the Hague Sales Convention: 543. et. seq.

${ }^{44}$ Compare with Knapp, Ch. L.: in: Bianca-Bonell: Commentary on the International Sales Law. op. cit. 540. et. seq.; Stoll, H.: in: Schlechtriem (Hrsg.): Kommentar zum einheitlichen UN-Kaufrecht (CISG). 698. et. seq., 714. et. seq.; Sándor: International Sales. 275. et. seq. 
working documents of the Vienna Agreement there was no intention or impetus for significant changes.

As opposed to the negligence based contract liability law found in the Code civil and the BGB, Article 79 of the Vienna Sales Convention, as was pointed to earlier, mandates a higher standard of reason in granting liability relief. The introduction of the foreseeability doctrine into the rules of the Convention is essentially the supplementation of this more stringent system of relief. When liability for compensation is not linked to negligence of the party in breach then the entire risk for damages inherent in contract violation rests with the party in breach, although only to the extent that was possible to predict at the time of entering the contract. Commentaries all emphasize the close connection of the concepts of nonnegligence based liability and liability limited to foreseeable damages. These two principles provide the fundamental pillars of the liability system of the Vienna Convention. The basic idea behind this system of liability is that a contract performs its function of interest protection if the consequences of a possible breach do not thesubjective culpability of the party in breach, butthe risk he takes on is limited to that which he could clearly judge and knowingly take on at the time of entering into contract. ${ }^{45}$ It is important to repeat: the foreseeability doctrine is given a primary role particularly in cases where there is a system of relief less forgiving than the requirement of non-negligence. Finally, it is also worth noting that contributing to the internal balance of the system of damage liability found in the Vienna Convention is another rule according to which awards of compensation are not limited to cases of "fundamental breachof contract" (Article 25).

2. As we briefly showed earlier the foreseeability doctrine was fully developed in English and American judicial practice. It is important to observe however that there are differences between the contemplation rule found in English common law and the foreseeability doctrine found in the ienna Convention, just as Article 74 of the Vienna Convention deviates from Article 1150 of the Code civil.

a) Of these differences we need to emphasise the notion that, at least as a starting reference, common law treats as the upper limit of awardable compensation those damages that could be contemplated by both parties. ${ }^{46}$ 46 In contrast, the Vienna Convention, similarly to Article 1150 of the

\footnotetext{
${ }^{45}$ Same view by Rabel as well: Das Recht des Warenkaufs. op. cit. 495.

${ }^{46}$ The Hadley v. Baxendale decision states this point explicitly: "contemplation of both parties": (1854) 9 Exch 341, 354.
} 
Code civil, ${ }^{47}$ limits liability to only those damages that could be predicted by the party i.b. ${ }^{48}$ It is to be noted that more recent English decisions, although still always referring to Hadley v. Baxendale, essentially focus on examining foreseeability only on the side of the party i.b. ${ }^{49}$ Despite some uncertainty a similar tendency can be observed in American judicial practice as well ${ }^{50}$ and the UCC specifically provides this very rule, which we even quoted earlier.

Even as a general attitude common law tends not to subject to compensation damages that could not be forecast with good probability at the time of contracting. This exclusion applies not only in the case of tort damages, but also in judging contractual damages. ${ }^{51}$ The Vienna Convention is clear: it is sufficient enough reason if the breaching party could calculate the damage as the "possible consequence" of his breach. The "possible" nature of the resulting damage is not a strict prerequisite requirement. We can support the position that the "possible" nature of the occurrence of damage is to be judged on a case by case basis and it cannot be fixed in a general manner as with the use of a predetermined percentage. ${ }^{52}$

b) According to actively held belief the foreseeability doctrine of the Vienna Convention is to be applied in cases of negligence and even in cases of intentional breach of contract. In this regard the Vienna Convention deliberately diverges from the "source rule" of Article 1150 of the Code civil which, as we pointed to before, excludes the use of the foreseeability doctrine in the case of intentional breach of contract. We should mention, however, that an opinion exists according to which the principles and general spirit of the Vienna Convention suggest we consider not using the

\footnotetext{
${ }^{47}$ Mazeaud, H.-Mazeaud, L.-Mazeaud, J.-Chabas, F.: Traité théorique et pratique de la responsabilité civil délictuelle et contractuelle. No.'s 2381-2382.; Viney: La responsabilité: effets. op. cit. 323.

${ }^{48}$ Stoll, in: Schlechtriem (Hrsg.): Kommentar zum einheitlichen UN-Kaufrecht (CISG) op. cit.; Magnus: Wiener UN-Kaufrecht (CISG), in: Staudingers Kommentar zum BGB. Art. 74, Rn. 31.

${ }^{49}$ Most explicitly in the Czarnikow Ltd. v. Koufos (The Heron II) case: [1966] 2 Q.B. 695, 730 (C.A.)

${ }^{50}$ Redgrave v. Boston Symphony Orchestra, Inc.: 602 F. Supp. 1189, 1212 (D. Mass. 1985), 855 F. 2d 888 (1st Cir. 1988), 488 U. S. 1043 (1989).

${ }^{51}$ See for example the decision of the House of Lords in The Heron II case: [1969] 1 A.L. 350; similarly to Restatement of Contracts 2d, § 351.

${ }^{52}$ Same way Faust: Die Vorhersehbarkeit des Schadens. 33. et. seq. 331.
} 
liability limiting tool of the foreseeability doctrine in cases of intentional breach. ${ }^{53}$

3. According to the Vienna Convention foreseeability is an express and exclusive requirement related only to the contracting party's possible damage and its size. Consequently, this requirement does not link the act of breach itself or its possibility with the causal relationship, because such an expansion of foreseeability would influence not only the size of the damage to be compensated but also the basis of liability. Furthermore, this would introduce into the required conditions of liability a new element of culpability not known in the Vienna Convention. ${ }^{54}$

In the case of defective performanceof the contract it is particularly important to limit the requirement of foreseeability to the damage itself, because in these cases the application of the foreseeability doctrine is not very appropriate and indeed often impossible. ${ }^{55}$ Damage caused by a hidden fault is obviously not something the obligor could be aware of at the time of entering the contract or even during its execution, though he must carry the responsibility for it regardless. ${ }^{56}$ Most likely this is the reason why, as we mentioned before, the UCC treats this kind of damage case differently. ${ }^{57}$

In the context of defective performanceof the contract with regard to the so called consequential damages, it is not possible to mitigate liability of the party i.b. on the basis that he did not foresee the damages or that it was under no obligation to predict them as these damages had to be taken

${ }^{53}$ Enderlein, F.-Maskow, D.-Strohbach, H.: Internationales Kaufrecht. Berlin, 1991, Art. 74., Anm. 8. Later we mention the European Principles (Article 9. 503.) which also does not limit responsibility to only those damages that were not foreseeable in cases of intentional or grossly negligent behavior resulting in damage.

${ }^{54}$ For the uniform opinions in legal literature see Stoll: in: Schlechtriem (Hrsg.): Kommentar zum einheitlichen UN-Kaufrecht (CISG) 715. with footnote No. 152.

${ }^{55}$ Compare with Hellner: The Limits of Contractual Damages in the Scandinavian Law of Sales. op. cit. 75.; Dölle-Weitnauer: Einheitskaufrecht. op. cit. 546. et. seq.

${ }^{56}$ Consequently the decision reached in LG Duisburg v. 16. 7. 1976 is erroneous brought (still) under the Hague Sales Law. Compare Stoll: in: Schlechtriem (Hrsg.): Kommentar zum einheitlichen UN-Kaufrecht (CISG). 716. with in footnote No. 153. It should be mentioned however that even von Caemmerer would make the seller liable for faulty performance (given that he is not operating an established business) only if he ought to have recognized the problem ahead of time. von Caemmerer: Probleme des Haager einheitlichen Kaufrechts. AcP 1978. 121-149. (149.)

${ }^{57}$ UCC § 2-715(2)(b), compare with Schwenzer: Freizeichnung des Verkäufers von der Sachmängelhaftung im amerikanischen und deutschen Recht. op. cit.. 
into account by the party i.b. under all circumstances. Consequently, in these cases liability for compensation can generally only be mitigated based on a circumstance where the injured party is at fault for the damage, for example as in the case of improper use of a product conflicting with guidelines established by the maker. ${ }^{58}$ We note here that the obligeeis of course obliged even under the foreseeability doctrine to prevent or damagesdamage. ${ }^{59}$

At the same time we can observe in legal literature a clear tendency to expand the interpretation of the foreseeability doctrine to include possibly all damages in all breach of contract cases. According to this view the foreseeability doctrine should be interpreted in a way that the party i.b. is to be liable for even those damages that a logically reasoning person in his position ought to have calculated with. This interpretation would also give the judge deliberation power over the issue of logical distribution of damages or risk of damage between the contracting parties. ${ }^{60}$ This interpretation in and of itself is acceptable because it can be deducted from the expression „ought to have foreseen". However, even this way of interpreting Article 74 of the Vienna Convention gives no particular help in evaluating the scope of the effects of defective performance. Therefore, with regard to this problem, ${ }^{61}$ that opinion appears more convincing which challenges the „omnipotent" nature of the foreseeability doctrine. Instead of the „normative” concept of the foreseeability doctrine recommended by Stoll it is indeed more realistic in the case of d.p. to disregard the foreseeability doctrine which is a frequently inadequate requirement in this area. Instead, if the particular case calls for it, it is better to limit the liability of the breaching party for reasons of the injured party itself being at fault.

${ }^{58}$ Magnus: Wiener UN-Kaufrecht (CISG), in: Staudingers Kommentar zum BGB. Art. 74, Rn. 46-47. Magnus nevertheless sees a role for the foreseeability doctrine in determining the degree of likeliness of an existing damage: ibid. 46.

${ }^{59}$ Same Hellner: The Limits of Contractual Damages in the Scandinavian Law of Sales. op. cit. 78 .

${ }^{60}$ This view is foremost represented in Stoll: in: Schlechtriem (Hrsg.): Kommentar zum einheitlichen UN-Kaufrecht (CISG). op. cit. 716. with footnote No. 154.; Schlechtriem: Internationales UN-Kaufrecht. Tübingen, 1996, 169. et. seq., 171. et. seq.; Magnus: Wiener UN-Kaufrecht (CISG), in: Staudingers Kommentar zum BGB. Art. 74, Rn. 35.

${ }^{61}$ Faust: Die Vorhersehbarkeit des Schadens... op. cit. 34. et. seq., 273. et. seq., 331. et. seq. 
We note here that in charging the injurious party only those mitigating circumstances are allowed that were actually known to him, but not those that he ought to have known. ${ }^{62}$

4. Taking into account that the foreseeability standard of the Vienna Convention fixes the distribution of risk between the contracting parties to the time of contracting it is commonly held that the breaching party is not liable for damages that become apparent after the time of contracting (even if the time of appearance is prior to the breach). ${ }^{63}$ This view may present legitimate questions with regard to effective prevention of loss as was pointed out in comparing the solutions found in the BGB and the Vienna Convention. Perhaps this recognition is the root of those more recent American decisions that are beginning to treat as foreseeable damages those damages that become apparent from post-contracting disclosure of imminent risk of damage. ${ }^{64}$

As far as the discernability of damage itself is concerned we should underline the following based on commentary found in the literature: ${ }^{65}$ on the one hand, it is not sufficient proof of existing liability for damages of

${ }^{62}$ Same way Faust: ibid. 269., 307. et. seq.

${ }^{63}$ Knapp: in: Bianca-Bonell: Commentary on the International Sales Law. op. cit. 542.; Magnus: Wiener UN-Kaufrecht (CISG), in: Staudingers Kommentar zum BGB. Art. 74, Rn. 38.; Stoll: in: Mádl-Vékás: International Private Law and Law of International Economic Relations. 717.

${ }^{64}$ See Faust: Die Vorhersehbarkeit des Schadens decisions analyzed on 114. et. seq.; compare with Eisenberg: The Principle of Hadley v. Baxendale. Cal. L. R. 1992, 563-613. Eisenberg summarizes his opinion as follows (599. et. seq.): „Finally, reasonable foreseeability should be determined as of the time of breach, so the in deciding whether to breach the seller must sweep into its calculus all the costs that it should reasonably foresee will be incurred by the buyer as a result of breach. Application of the foreseeability standard at the time of breach, rather than at the time the contact is made, gives precedence to the rate of efficient breach over the rate of precaution. However, it is inescapable in this context that one of these rates must dominate the other. It is preferable to give precedence to efficient breach, because in practice the rate of precaution is likely to depend on contractual allocations of loss and precontract judgments based on probability, rather than on in formation communicated at the time of contracting. Moreover, contracting parties should not be encouraged to make decisions on breach that fail to sweep into their calculus all costs that are reasonably foreseeable at the time the decision is made."

${ }^{65}$ Knapp, in: Bianca-Bonell: Commentary on the International Sales Law. op. cit. 541.; Stoll: in: Schlechtriem (Hrsg.): Kommentar zum einheitlichen UN-Kaufrecht (CISG). 717.; Faust: Die Vorhersehbarkeit des Schadens. op. cit. 238. et. seq. 
the party i.b. that he was aware of the nature of the impending damage (as in the possibility of lost profit) at the time of contracting. On the other hand, it is not an additional requirement of finding of liability that the party i.b. know the actual monetary valueof the damage at the time of contracting. ${ }^{66}$ Liability is defined by the scope of the knowledge the party i.b. possessed or ought to have possessed about the nature and potential magnitude of the damage at the time of contracting. This is how the purpose of the norm can be achieved which is the pre-contracting ability to assess and plan for risk to be assumed. For example, if the breaching seller was aware at the time of contracting that the buyer was getting the contractual goods for resale, but the buyer did not disclose the actual amount of profit he expected to gain by his personal speculation, then the seller is responsible for lost profit only to the extent that general market conditions would imply, but he does not have to pay for any additional lost profit even if it could actually be proven by the buyer to have been achievable based on his speculation in the particular case. Of this speculative profit the seller did not know or had to have known at the time of contracting. ${ }^{67}$

5. The foreseeability doctrine has considerably different significance in various kinds of breaches and damages. This was pointed out on several occasions earlier, it seems practical, however, to summarize.

a) In the case of non-performance delayed performance turning into impossibility of performance the party i.b. must always consider as a possible loss the price of the goods on open market and administrative costs/overhead. This is so even when the market price of goods under contract is significantly higher at the time of covering purchase than it was at the time of contracting. According to common understanding the usual fluctuation of market prices is part of the risk of doing business and the would-be violator assumes the resulting liability by entering intocontract. ${ }^{68}$ The same conclusion can be drawn from the interpretation of Article 74 as well. Damages resulting from the fluctuation of market prices must be categorized as those

${ }^{66}$ Same view by Rabel as well: Das Recht des Warenkaufs. op. cit. 509.

${ }^{67}$ Stoll's example: in: Schlechtriem (Hrsg.): Kommentar zum einheitlichen UNKaufrecht (CISG). 717.

${ }^{68}$ The situation isn't as straightforward in the case of loss the entitled suffers as a result of late payment and subsequent foreign currency exchange where the transaction is completed at a conversion rate that had changed in an unfavorable direction when viewed from the entitled's perspective. Compare with Faust: Die Vorhersehbarkeit des Schadens. op. cit. 21. et. seq. 
consequences of breach that had to be foreseen at the time of contracting. Naturally, in this case as well (as usual ${ }^{69}$ ) the injured is expected to mitigatedamages just the same in accordance with Article $77 .^{70}$

There is a similar situation when the obligeehas to take out a loan in order to balance the consequences of the breach. Interest on such a loan is to be paid by the party i.b. and related expenses incurred as the result of any appropriate action taken to prevent or mitigate damages (such as freight forwarding, warehousing, inspection, etc.) must also be covered. The solution is the same with regard to other costs and related expenses resulting from the repairing of the damage.

We can say generally that the necessary cost and expense of averting the breach itself (as a form of damage) is the responsibility of the breaching party and the foreseeability doctrine has no bearing on this matter. This appears to be the correct view, although Articles 75 and 76 of the Vienna Convention contain a reference to Article 74 when regulating elimination of loss in covering sales and purchases as well as short sales. This legislative solutioncould theoretically mean that the foreseeability doctrine (as in the second sentence of Article 74) is in effect in this case as well. However, based on consensus on this matter the application of the foreseeability doctrine is correctly ruled out. Grammatical analysis in and of itself points in this direction: both Articles 75 and 76 talk about "other damages" established by Article 74 to be compensated, in this way automatically ruling out the foreseeability doctrine going into effect with regard to these damages. This view is further supported by arguments based on legislative history, ${ }^{71}$ and on the system and the purposes of the Convention. ${ }^{72}$

We have already pointed out that the foreseeability doctrine cannot be adequately utilized in the case of so called consequentialdamages that is in the case of reparations for defectiveperformance by way of compensation.

b) As it is already clear from the preceding discussion, the true target of influence for the foreseeability doctrine is the issue of compensation for consequential damages and above all for unrealized profit in cases of

${ }^{69}$ Faust: Die Vorhersehbarkeit des Schadens. op. cit. 297. et. seq.

${ }^{70}$ Magnus: Wiener UN-Kaufrecht (CISG), in: Staudingers Kommentar zum BGB. op. cit. Art. 74., Rn. 40-41.

${ }^{71}$ Stoll: in: Schlechtriem (Hrsg.): Kommentar zum einheitlichen UN-Kaufrecht (CISG). op. cit. 718., footnote No. 166.

${ }^{72}$ Faust: Die Vorhersehbarkeit des Schadens. op. cit. 26. et. seq., 329. 
breach of contract. ${ }^{73}$ These damages are namely often connected to circumstances that are not known to the breaching party and could not have been known without the disclosure of theobligee. Consequently, in order for the affected contracting party to be able to measure the risk and the cost of its coverage and based on these have the ability to make an informed decision about whether to contract at all, or about counterperformance and possible limiting of liability, he must be informed about the risks related to unrealized profit and consequential damages at the time of contracting. Or if such notice cannot be given because even the other party has no information on consequential damages that may result from a possible breach, or perhaps the party in possession of such information has overriding interests that run counter to sharing details of his trade secrets, for example, in order to protect his market position or business strategy then the breaching party is exempted, based on the foreseeability doctrine, from liability for compensation of those damages that he did not know or had to have known at the time of contracting.

According to common understanding the party i.b. is only liable to compensate the obligeefor expected but unrealized profit from planned resale if the intent of resale was know to him at the time of contracting. If the buyer is a merchantand the subject of the contract is commercial goods then the obligor must, even without any pertinent additional notice, calculate with resale and its resulting benefits that in the case of breach manifest themselves as unrealized profit. ${ }^{74}$ Similarly, if the buyer of real estate is a firm engaged in the business of trading or leasing real estate, the seller must calculate with profit from resale as unrealized profit if the contract is breached. Also similar is the case when at the time of contracting it is known to a transportation outfit that the raw materials they are contracted to deliver are intended for processing in the client's plant and there is an intent of eventual sale of the finished product.

In the same category we find the example of such cases where the breach forces the obligee's plant to temporarily suspend operation which causes a realistically expected profit not to materialize. ${ }^{75}$ On the contrary,

${ }^{73}$ The same conclusions were reached by Hellner's comparative law analyses as well: The Limits of Contractual Damages in the Scandinavian Law of Sales. op. cit. 78.

${ }^{74}$ Rabel: Das Recht des Warenkaufs. op. cit. 509. A similarly principled court decision is quoted from the application of the Vienna Convention Stoll: in: Schlechtriem (Hrsg.): Kommentar zum einheitlichen UN-Kaufrecht (CISG). op. cit. 718., with footnotes No. $168-169$.

${ }^{75}$ Same way Magnus: Wiener UN-Kaufrecht (CISG), in: Staudingers Kommentar zum BGB. op. cit. Art. 74, Rn. 40. 
there are opinions in the literature that hold the party i.b. responsible for such a loss only if explicit prior notice was given of the danger of a possible temporary shutdown of operations. The rationale behind this train of thought is that in the absence of such warning the breaching party can assume that theo., being a professional practitioner of his trade or business, is himself prepared for just such an eventuality, possessing tools to avert loss, for example by stockpiling surplus inventory of spare parts, etc. ${ }^{76}$

c) Similarly to unrealized profit, the foreseeability doctrine provides a guideline for those cases as well where the entitled suffers a loss due to the circumstance whereby the breach of his contracting partner prevents him from performing another contract with a third party, and he therefore becomes liable for compensation or other reparation (for example, obligations under a warranty) to the third party. If o.is a business person, obligor must without any express warning consider this consequence and therefore must be responsible for this kind of loss. ${ }^{77}$ However, if the o.has taken on commitments toward the third party outside of or surpassing what is legally sanctioned (special guarantee or higher than industry-standard penalty for non-performance, etc.) he may transfer liability for the consequences of such commitments to the party i.b. only if he informed the would-be breaching party of the possibility of such damages occurring at the time of contracting or if the contracting party had to have independently known of these extra commitments. ${ }^{78}$

d) The literature generally shows an even stricter standard when providing guidelines for the transfer of liability where harm to the entitled's goodwill is at stake as the consequence of breach (as in defective performance where the damage may take the form of loss of clientele. Even such an opinion exists that the o.may only enforce claims of such damages against the breaching party if at the time of contracting he gave express notice of

\footnotetext{
${ }^{76}$ Schlechtriem: Internationales UN-Kaufrecht. op. cit. 171. It is interesting to observe that the judges reached a similar position in Hadley v. Baxendale as well. The loss at issue is seen even more firmly, as a matter of general principle, by von Caemmerer as the liability of the entitled: von Caemmerer: Probleme des Haager einheitlichen Kaufrechts. op. cit. 147.

${ }^{77}$ A similar court decision from the practical application of the Vienna Convention: Magnus: Wiener UN-Kaufrecht (CISG), in: Staudingers Kommentar zum BGB, Art. 74, Rn. 45.; Stoll: in: Schlechtriem (Hrsg.): Kommentar zum einheitlichen UNKaufrecht (CISG). op. cit. 719., footnote No. 172.

${ }^{78}$ Same way Stoll: ibid. 719. with footnote No. 173.
} 
such possible damage. ${ }^{79}$ A case adjudicated based on the Hague Sales Convention by the German Bundesgerichtshof found loss of goodwill and foreseeability of loss of business on the grounds of a trade usagefound in the particular business sector involved. ${ }^{80}$

e) We should mention here that with the evolution of product liability laws a significant portion of consequential damages resulting from defective.perf.is governed by separate rules. ${ }^{81,82}$

6. It is difficult to arrive at a conclusive position on the allocation of burden of proof linked to issues of foreseeability.

a) There are various conflicting positions in English legal practice. ${ }^{83}$ Nevertheless, according to a majority or perhaps even prevailing attitude the burden of proof rests with the adversely effected party. ${ }^{84}$ It is his responsibility to prove that the loss at hand could be or at least ought to have been foreseen by the breaching party. A similar attitude is reflected in American decisions as well. ${ }^{85}$

${ }^{79}$ Same Magnus: Wiener UN-Kaufrecht (CISG), in: Staudingers Kommentar zum BGB, Art. 74, Rn. 50.; Stoll: in: Schlechtriem (Hrsg.): Kommentar zum einheitlichen $U N$-Kaufrecht (CISG). op. cit. 719. (for differing views see: same place footnote No. 175.).

${ }^{80}$ BGH 24.10.1979, quoted by Faust: Die Vorhersehbarkeit des Schadens. op. cit. 21. with footnote No. 94.

${ }^{81}$ In Hungarian Law the rules of Law No. 10 of 1993 , which need to be fully integrated into the Code during the reform process of the C.C..

${ }^{82}$ This view was held even at the beginning stages of European product liability law Hellner: The Limits of Contractual Damages in the Scandinavian Law of Sales. op. cit. 79.

${ }^{83}$ McGregor: On Damages. op. cit. 83. (item No. 138.).

${ }^{84}$ Lord Summer in S. S. Singleton Abbey v. S. S. Paludinas, [1927] A.C. 16, 2526; further cases found with McGregor: On Damages. op. cit. footnote No. 2.; same way Lord Merriman P. in The Guildford case, [1956] P. 364, 370. Contrary view: if the party causing the damage wants not to be compelled to compensate for damages he should argue that the given damage could not be foreseen: Lord Haldane and Lord Dunedin in The Metagama case, [1927] 29 L1.L. Rep. 253, 254, 256 (Lord Dunedin's opinion dissenting judgment). In his commentary McGregor also holds the view that the injured is charged with the burden of proof. He adds that although all referenced cases are about tort damages, he sees no reason not to accept the same rule as a general one to be applied in all cases, including those of contractual damage.

${ }^{85}$ Redgrave v. Boston Symphony Orchestra, Inc.: 602 F. Supp. 1189, 1212 (D. Mass. 1985), 855 F. 2 d 888 (1st Cir. 1988), 488 U. S. 1043 (1989); Larsen v. A.C. Carpenter, Inc., 620 F. Supp. 1084, 1132 (E.D.N.Y. 1985), 800 F. 2d 1128 (2d Cir. 1986); Lassen v. First Bank Eden Prairie, 514 N. W. 2d 831, 838 (Minn. Ct. App. 1994). 
However, in French literature the opposite can be observed. Majority opinion puts the burden of proof on the party i.b., that is in order to be granted relief it is the breaching party whois asked to prove that the given loss could not be foreseen or that he ought not have been expected to foresee it. ${ }^{86}$ However, we should note that possibly among the reasons for this thinking are considerations of procedural law. ${ }^{87}$

In short, we can say that there is no consensus among those legal systems that serve as a foundation for the Vienna Convention in the matter of allocating burden of proof of foreseeability. Considering, however, the larger practical scope of the English and American cases it is more prevalent that the adversely affected party is actually charged with the task of proving foreseeability.

b) Wiews reflected in literature dealing with Article 74 of the Vienna Convention are also remarkably split when it comes to the issue of allocating proof.

Some simply reasonfrom the position that the foreseeability rule is a norm that is specific to the general rule of full compensation (1st and 2 nd sentence of Article 74) and, consequently, burden of proof rests with the breaching party causing the damage. This view incorporates the understanding that preconditions of liability for damages (breach of contract, chain of causation, damage and its size) must be proven by the injured party, while the lack of foreseeability as grounds for partial relief must be shown by the injurious party. ${ }^{88}$ Magnus corrects this view in that he suggests the injured party must prove that the breaching party knew the relevant circumstances, especially those contributing to elevated levels of risk, or at least had to have known them. ${ }^{89}$

${ }^{86}$ Lalou, H.-Azard, P.: Traité pratique de la responsabilité civile. Paris, $1962{ }^{6}$, item No. 495.; le Tourneau, Ph.: La responsabilité civile. Paris, $1982^{3}$, item No. 246. Chartier as a general rule also places the burden of proof with the injurious party, but in the case of the problem that actually occurs most commonly, that of consequential damages, he holds the opposite view; according to him the assumption can be effectively challenged that the given damage was not foreseeable: Chartier, Y.: La réparation du préjudice dans la responsabilité civile. Paris, 1983.

${ }^{87}$ Compare with Faust: Die Vorhersehbarkeit des Schadens. op. cit. 190. footnote No. 739.

${ }^{88}$ Enderlein-Maskow-Strohbach: Internationales Kaufrecht. op. cit. Art. 74, item No. 10.

${ }^{89}$ Magnus: Wiener UN-Kaufrecht (CISG), in: Staudingers Kommentar zum BGB. op. cit. Art. 74, Rn. 62. 
The contrasting position considers the foreseeability doctrine itself to be part of the foundation of liability and therefore puts the related burden of proof on the injured party. According to the authors referred to earlier this solution is supported by the central thesis of the foreseeability doctrine: at the time of entering into contract the future breaching party had to know the resulting risk. So a position that would stipulate that the breaching party calculated with (or at least ought to have calculated with) all of the proven damage at the time the contract was concludedwould be at odds with this correct legal policy foundation at the heart of foreseeability. To the contrary, the party i.b. mayonly be held responsible for covering those risks of damage that he was proven by the injured party to have taken on as contractual obligations. This view therefore does not consider the foreseeability doctrine to be a rule of exception, rather it is understood to be part of the general rules of conditions of liability, in a sense equating foreseeability with the concepts themselves of breach, damage and the link of causality between the two. ${ }^{90} \mathrm{We}$ consider this latter position to be correct, especially considering that the achievement of the purpose of the foreseeability doctrine necessitates this solution because in order for the future breaching party to be able to make well founded and calculated decisions about taking on risk at the time of contracting, the future injured party must provide facts that create the condition for him to be in an appropriately informed state. Essentially, the future injured party has to be charged with providing the conditions, by way of adequate dissemination of information, for his contractual partner to be able to make decisions in the matter of taking on risk and calculating pricing accordingly, based on the largest possible degree of familiarity with the probability of risk of damage.7. Article 74 of the Vienna Convention is yet to produce signs of significant application in judicial practice. Even commentaries use cases connected to the Hague Convention on Sales for illustration. Nevertheless, we see a fundamentally well formed doctrine in foreseeability, reflected in the fact that this principle's essence is echoed by recent model laws.

UNIDROIT Principles of International Commercial Contracts (1994) ${ }^{91}$ determines the breaching party's liability for damages independently offault

${ }^{90}$ Stoll: in: Schlechtriem (Hrsg.): Kommentar zum einheitlichen UN-Kaufrecht (CISG). op. cit. 721.; Faust: Die Vorhersehbarkeit des Schadens. op. cit. 324. et. seq., 333., certain irrelevant restrictions: 325., 326. et. seq.

${ }_{91}$ Among others the text is published in Eu. J. Law Reform, Issue No. 1998/99.: $345-363$. 
and excuses him from liability only on the basis of an impediment beyond his control such asvis maior. ${ }^{92}$ Article 7.4.4 states: „The non-performing party is liable only for harm which it foresaw or could reasonably have foreseen at the time of the conclusion of contract as being likely to result from its non-performance". ${ }^{93}$ The meaning of this rule coincides with that of the norm found in Article 74 of the Vienna Convention, and it differs only in its phrasing slightly. Such a difference exists between „could reasonably have foreseen" versus „ought to have foreseen" and ,as being likely to result from" instead of ",as a possible consequence". We should remark that in the system of UNIDROIT Principles the concept of „nonperformance" universally applies to all forms of contract. ${ }^{94}$

I believe that in comparing the norm of the UNIDROIT Principles with Article 74 of the Vienna Convention the former leaves less of a doubt that the foreseeability doctrine belongs to the definition of damage as a precondition of liability of the party i.b. (Articles 7.4.2 and 7.4.3), therefore the burden of its proof rests with the injured party.

b) The Principles of European Contract Law (1997) also finds liability of the non-performing party independently of fault ${ }^{95}$ and the foreseeability doctrine is used here to supplement this principle (Article 9.503). ${ }^{96}$ This solution differs from the norms established in the UNIDROIT Principles

${ }^{92}$ Article 7.17., Force Majeure: Non-performance by a party is excused if that party proves that the non-performance was due to on impediment beyond its control and that it could not reasonably be expected to have taken the impediment into account at the time of the conclusion of the contract or to have avoided or overcome it or its consequences

${ }^{93}$ The non-performing party is liable only for harm which it foresaw or could reasonably have foreseen at the time of the conclusion of contract as being likely to result from its non-performance.

${ }_{94}$ Article 7.1.1.: Non-performance is failure by a party to perform any of its obligations under the contract, including defective performance or late performance.

${ }_{95}$ Article 8.108.: A party's non-performance is excused if he proves that it is due to an impediment beyond his control and that he could not reasonably have been expected to take the impediment into account at the time the conclusion of the contract, or to have avoided or overcome the impediment or its consequences.

${ }^{96}$ The rule matches the norm found in the above mentioned UNIDROIT principles almost word for word. The only deviation is found in the case of damage caused by intentional or grossly negligent non-performance which is excluded from the sphere of application of the foreseeability clause: „The non-performing party is liable only for loss which he foresaw or could reasonably have foreseen at the time of conclusion of the contract as a likely result of his non-performance, unless the non-performance was international or grossly negligent." 
in two ways. The European Principles [article 9.501 paragraph (2) b)], as a matter of course, orders compensation of only that future loss ,which is reasonably likely to occur". At the same time, showing similarities with Article 1150 of the Code civil, it does not limit liability for damages via the foreseeability doctrine in cases of intentional or grossly negligent nonperformance. This latter solution, in our opinion, is not in satisfactory harmony with a system of liability independent of fault and is also at odds with the foreseeability doctrine which builds on considerations of distribution of risk along the principles of a free market, not to mention the complexity of burden of proof. ${ }^{97}$

\section{Conclusion and proposal de lege ferenda}

1. Particularly In a system of strict contractual liability that is independent of fault, the inclusion of an appropriate mechanism for limiting compensation is an absolute necessity. Among the known dogmatic resolutions leading to distribution of loss the foreseeability principle appears to be the most appropriate one to fulfill this role.

The foreseeability doctrine can be considered a proven tool of law in the distribution of market related or other contractual risk among contracting parties. It incites the o.to appropriately inform the obliged at the time of the conclusion of contract of the expected consequential damages resulting in the eventuality of breach, especially regarding the valueof the lucrum cessans and of the possible consequentialdamages. Knowing the risk of these damages is a condition of the obliged making an informed decision about whether to conclude the contract and under what conditions of counter-performance, possible limitation of liability, etc. Risk of damage that is unusually high because it significantly surpasses that which could be calculated as the normal consequence of the given contract can be known by the obligor only based on disclosure by theo.

b) By the same token, the foreseeability doctrine is a rather flexible tool in the hands of the judge in the distribution of loss caused by nonperformance among the parties, above all loss of expected profit and consequential damages. The foreseeability doctrine defines the conditions of distribution of loss more precisely than a statutory enpowermentto

\footnotetext{
${ }^{97}$ The same view is held on the system of responsibility under European Contract Law principles-based on well-founded reasoning-Faust: Die Vorhersehbarkeit des Schadens. op. cit. 314. et. seq., 333.
} 
reduction of damages based on the equity principle [for example C.C. 339. $\S$ paragraph (2)]. Moreover, particularly considering conclusions arrived at previously, it is a better fit for the attitude of contract law, market considerations, and business rationale.

2. A separate examination is required whether the foreseeability doctrine could be applied similarly in the case of tort damages. Naturally, in these cases issues mentioned under paragraph 1) have no relevance. Based on his analysis of German legal literature Tercsák finds the application of the foreseeability principle in limiting liability for damages in tort cases „rather confusing". ${ }^{98}$ It is of note, however, that judicial practice of common law applies the foreseeability doctrine even in tort cases rather effectively and a rule of the BGB [254. § paragraph (2)] that shares a common purpose with the foreseeability doctrine is itself not limited to contractual matters. In his study written for the Concept of the New (Hungarian) Civil Code Lábady suggests the introduction of the foreseeability doctrine in adjudicating matters of unrealized profit even in tort cases. ${ }^{99}$

3. Considering the above it appears advisable that, with the ongoing reform of the Hungarian Civil Code, the system of liability for contractual damages (besides the relief power being converted from a discretionary to a more objective one) be amended, above all, by the foreseeability doctrine that provides a foundation for limiting liability for damages. The norm found in the second sentence of Article 74 of the Vienna Convention could serve as a guide for this purpose in the new (Hungarian) Civil Code.

a) The foreseeability doctrine would theoretically apply to all cases of damage caused by non-performance, i.e. it could be structured accordingly, without relevant limitations. Both the experience built by foreign legal practice and views reflected in the literature seem to point uniformly to the understanding that the foreseeability doctrine will play a significant practical role primarily in the adjudication of matters of unrealized profit and consequential damages.

b) We ought to also consider, modeled after the UCC, that we exclude from the domain of the foreseeability doctrine those cases where the o.wishes that the party in breach should repair the defect in the performance itself

\footnotetext{
${ }^{98}$ Tercsák: (Foreseeability as the boundary of compensation...) op. cit. 251. et. seq.

${ }^{99}$ Lábady: Felelősség a serződésen kívül okozott károkért; a biztosítási szerződés. Polágir jogi kodifikáció III. [Liability for tort damages, the insurance contract. Civil Law Codification III] (2001) issue No. 4-5.
} 
in the form of damages (and not as a warranty claim). This is so because, as we pointed out earlier, the foreseeability doctrine is not a good fit for this kind of damage. It is to be noted that this would turn out to be a rather limited problem if the new Civil Code, as it is suggested by the Concept, would allow the making of claims of these damages" at issue only during the period of implied warranty and not throughout the general limitation period.

c) From the perspective of foreseeability the concept of relevant time is generally the time of conclusion of contract, or more precisely, the time when the obligor (the possible non-performer) makes a legal declarationt relevant from the perspective of the coming into existence ofthe contract. This is the time, namely, when the obliged can make contract forming decisions that are informed by knowledge of risk that correlates to his possible future liability. The relevant legal statement is typically the declaration of acceptance when the contract is actually concluded, but it could also be a declaration of offer.

Moreover, it is also to be considered based on recent American judicial practice that the non-performing party be positively held liable for damages that become known up to the time of a grossly negligent or intentionalbreach.

d) In the new Civil Code the uncertainty caused by the language of Article 74 of the Vienna Convention must be remedied so that it is clear that burden of proof related to the foreseeability doctrine rests on the injured party.

e) Finally, we should calculate with the possibility that the norms established by rules of particular types of contractcreate an exception from the general rules of liability and reparation of damages resulting from breach of contract. In our case this would mean an exception to the rule of foreseeability. ${ }^{100}$ Such a solution can be found in the effective Code as well among the rules of specific kinds of deposit (Civil Code $\S 467-468$, $\S$ 471 ), freight transportation ( $\$ 500$ and following), donations ( $\$ 581)$.

${ }^{100}$ Same way Hellner: The Limits of Contractual Damages in the Scandinavian Law of Sales. op. cit. 79. 